\title{
CHOROIDAL MALIGNANT MELANOMA IN A CHILD*†
}

\author{
BY. \\ SAMUEL T. JONES \\ Department of Ophthalmology, University of Texas Medical Branch, Galveston, Texas
}

\begin{abstract}
MALIGNANT melanoma of the choroid is very rare in children. The case reported here had the typical clinical features of a choroidal malignant melanoma, but the correct clinical diagnosis was not made because of the youth of the patient.
\end{abstract}

\section{Case Report}

A 10-year-old white girl had noted that the vision of the right eye was markedly diminished 2 weeks before she was first seen. There was progressive loss of vision afterwards. A school examination one year previously had shown the visual acuity to be 20/30 in each eye without correction. There was no history of strabismus. The patient's general health had been excellent and there was no family history of eye tumours.

Examination.-The anterior segments were normal except that the right pupil reacted sluggishly to light. There was a detachment of almost all the retina posterior to the equator in the right eye, and a large round yellow-white mass about 5 disc diameters across was present in the region of the equator in the lower temporal quadrant. This round lesion appeared to be attached to a larger, darker, ill-defined subretinal mass. The lower temporal quadrant did not transilluminate. There appeared to be a minimal amount of subretinal fluid between the retina and the top of the yellowwhite lesion.

The fundus of the left eye was normal except for three small areas of chorio-retinal atrophy in the temporal periphery.

Complete physical examination revealed no abnormalities except the lesion in the right eye.

Diagnosis.-The following clinical diagnoses were considered most likely: retinoblastoma, metastatic tumour (primary site unknown), inflammatory lesion due to Toxocara canis or other helminth. Although the possibility of malignant melanoma was mentioned, it was considered unlikely because of the patient's age.

The eye was enucleated and submitted for pathological study. It measured antero-posteriorly $24 \mathrm{~mm}$., horizontally $24 \mathrm{~mm}$., and vertically $24 \mathrm{~mm}$., and showed no external abnormalities. Transillumination before it was opened revealed a dark mass about one $\mathrm{cm}$. in diameter in the inferior temporal quadrant. Gross examination after calottes were cut revealed a mass about $1 \mathrm{~cm}$. in diameter, rounded, homogeneous, and grey, protruding into the inferior temporal portion of the vitreous cavity. This mass appeared to arise from the choroid. The retina, which was detached in most areas, appeared to be in contact with the top of the tumour.

Histological examination revealed that the large grey mass was composed of elongated cells with prominent nucleoli (Figure, overleaf). A number of cells contained dark brown pigment. The pathological diagnosis was malignant melanoma, spindle cell $\mathbf{B}$ type.

Result.-The patient is alive and well one year after the enucleation.

* Received for publication January 1, 1965 .

$\dagger$ Address for reprints: Department of Ophthalmology, University of Kansas Medical Center, Rainbow Boulevard at 39th Street, Kansas City, Kansas, 66103. 


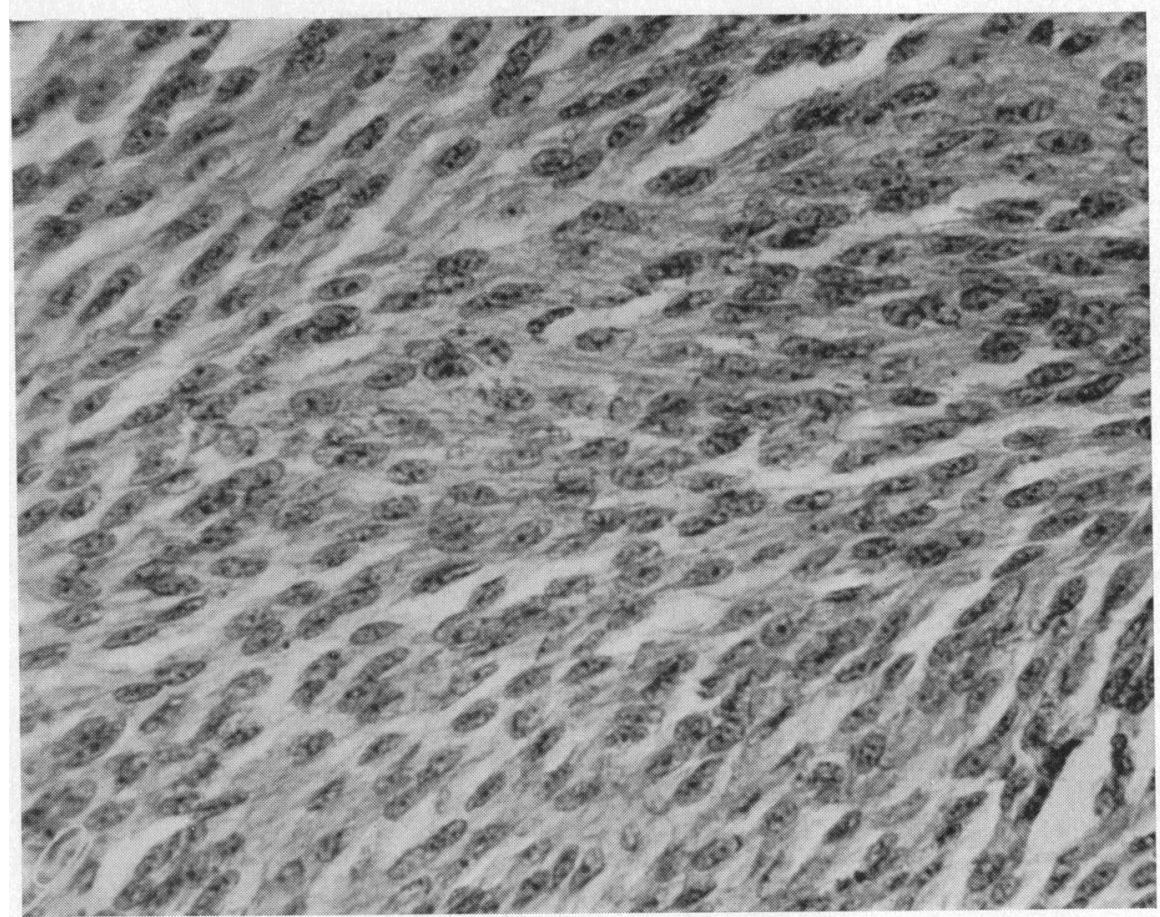

FIGURE-Histological section, showing spindle cells with prominent nucleoli. Haematoxylin and eosin. $\times 340$.

\section{Discussion}

It is a well-established fact that malignant melanoma is rare before puberty. Pack (1948) stated that he had never seen a prepubertal melanoma of the skin which was clinically malignant. Noting the change in pigmentation and growth of skin naevi which occur at puberty, he suggested a relationship between hormonal changes at puberty and the development of malignant melanoma. Subsequent reports indicated that, although true malignant melanomata of the skin are rare before puberty, they do occur (McWhorter and Woolner, 1954).

A serious challenge has never been made to Pack's suggestion that there is a relationship between puberty and the pathogenesis of malignant melanoma of the skin. A similar relationship of puberty to the development of ocular malignant melanoma has been suggested (Cury, Lucic, and Irvine, 1959; Apt, 1962). However, choroidal malignant melanomata do not show an abrupt increase in incidence at puberty, but rather a steady increase with advancing age (Paul, Parnell, and Fraker, 1962). This raises some doubt as to the importance of puberty in the pathogenesis of malignant melanoma of the choroid.

The extremely low incidence of malignant melanoma of the choroid in children was shown by Paul and others (1962), who found only four patients under 10 years of age in a group of 3,628 malignant melanomata of the choroid and ciliary body on file at the Armed Forces Institute of Pathology. Verdaguer (1965), reporting on melanomata in patients under 20 years of age, stated that four of his seven cases of malignant melanoma of the choroid had melanosis oculi. 
The classification of uveal malignant melanomata by cell type has the same general prognostic significance in children as in adults, spindle cell tumours being less lethal than epithelioid tumours (Apt, 1962). Several recent reports (Cury and others, 1959; Apt, 1962; Verdaguer, 1965) have suggested the possibility that some malignant melanomata in children may arise from the retinal pigment epithelium.

\section{Summary}

Malignant melanoma of the choroid occurs very rarely in children. A case in a 10 -year-old girl is reported, in which histological examination revealed that the tumour was a spindle cell B malignant melanoma.

This work was supported in part by USPHS Grant IT 8 NB 1004001.

\section{REFERENCES}

APT., L. (1962). Int. Ophthal. Clin., 2, 403.

CurY, D., Lucic, H., and Irvine, A. R. (1959). Amer. J. Ophthal., 47, no. 5, pt 2, p. 202.

MCWHORTER, H. E., and WOOLNER, L. B. (1954). Cancer, 7, 564.

PACK, G. T. (1948). Surg. Gynec. Obstet., 86, 374.

Paul, E. V., Parnell, B. L., and Fraker, M. (1962). Int. Ophthal. Clin., 2, 387.

VerdAGUer, J. (1965). Amer. J. Ophthal., 60, 1002. 